KOLOM ILMIAH

Social Humaniora

\title{
PEMBERDAYAAN PETANI JAGUNG ORBA (ORONG BAWA) MELALUI PENGEMBANGAN USAHA DIVERSIFIKASI PRODUK OLAHAN JAGUNG SEBAGAI UPAYA MENINGKATKAN NILAI TUKAR PETANI
}

\author{
Didi Suwardi ${ }^{1}$, Dinar Suksmayu Saputri ${ }^{2}$, Fitriah Permata Cita ${ }^{3}$ \\ ${ }^{13}$ Fakultas Ekonomi dan Binis, Universitas Teknologi Sumbawa \\ ${ }^{2}$ Fakulas Teknologi Pertanian, Universitas Teknologi Sumbawa \\ Coresponding email: didig@ymail.com
}

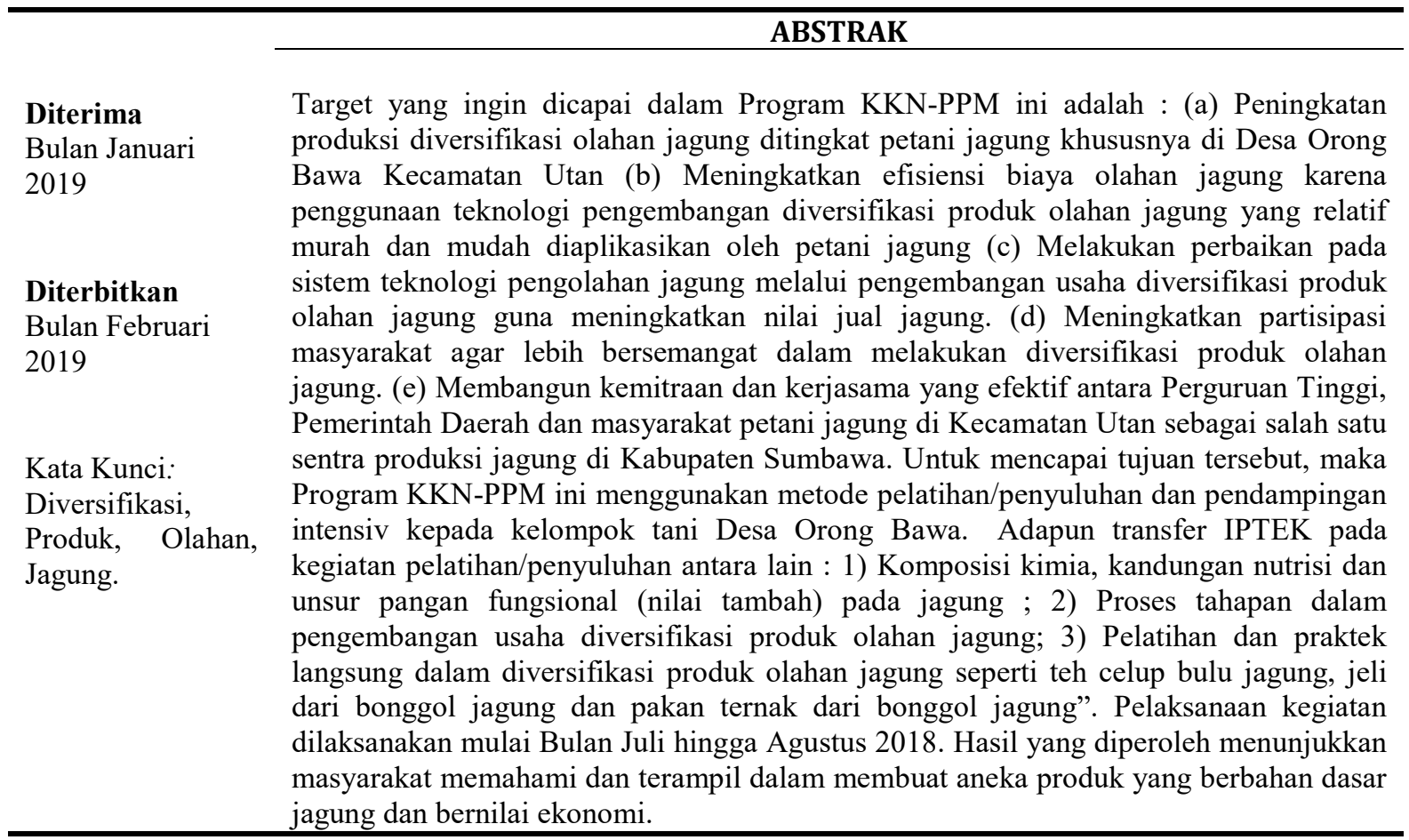

\section{PENDAHULUAN}

Pertanian merupakan sektor basis di Kabupaten Sumbawa dengan jagung sebagai komoditi unggulannya. Jagung merupakan tanaman serealia yang termasuk bahan pangan penting karena merupakan sumber karbohidrat kedua setelah beras (Purwono et al., 2011). Produksi jagung di Kabupaten Sumbawa meningkat dari tahun ke tahun, pada tahun 2011 misalnya produksi jagung sebesar 132.554 ton dan meningkat menjadi 329.885 ton pada tahun 2016. Apabila dibreakdown per kecamatan maka Kecamatan Utan merupakan salah satu sentral produksi jagung di Kabupaten Sumbawa dimana pada tahun 2011 produksi jagung sebesar 13.292 ton dan 22.615 ton pada tahun 2016 Dimana Desa Orong Bawa merupakan salah satu sentral produksi jagung terbesar hal ini sejalan dengan luas lahan yang mencapai 542,75 Ha atau 22,27 dari luas lahan sawah yang ada (Dinas Pertanian Kabupaten Sumbawa 2017 dan BPS Kabupaten Sumbawa).
Luasnya areal dan tingginya produksi jagunag di Desa Orong Bawa tidak berkorelasi positif dengan pendapatan petani hal ini tercermin dari masih banyaknya keluarga miskin. Data BPS Kecamatan dalam angka menunjukkan bahwa pada tahun 2015 tingkat kesejahteraan penduduk Desa Orong Bawa dimana jumlah KK Prasejahtera berjumlah $56 \mathrm{KK}$ atau sekitar 14,93\% dari jumlah KK di Orong Bawa. Masih banyakanya keluarga prasejahterah di Desa Orong Bawa disebabkan karena rendahnya pendapatan rumah tangga yang mayoritas mengandalkan hidup dari kegiatan pertanian..

Secara umum masalah dan kendala utama yang dihadapi Petani Jagung di daerah Orong Bawa adalah belum adanya upaya dan pengembangan yang baik dalam usaha diversifikasi produk olahan jagung yang berdaya jual tinggi dan bernilai ekonomis. Kondisi ini dikarenakan masyarakat petani daerah ini belum mengenal teknologi pengolahan tersebut. Selain itu, minat masyarakat 


\section{JURNAL TAMBORA}

Vol. 3 No. 1 Februari

2019

terhadap pangan berbasis jagung masih rendah. Hal ini disebabkan oleh kurangnya pengetahuan sebagian masyarakat tentang nilai gizi jagung, tampilan produk pangan dari jagung yang kurang menarik, dan adanya anggapan bahwa jagung hanya dikonsumsi oleh masyarakat berekonomi lemah. Maka dari itu, perlu dilakukan pengembangan usaha diversifikasi produk olahan jagung dengan keterpaduan berbagai aspek yang saling terkait satu sama lainnya, yaitu aspek produksi, aspek pengolahan, aspek pemasaran dan konsumsi.

Salah satu program yang sangat strategis mendukung kemitraan dalam bentuk pemberdayaan masyarakat petani jagung adalah melalui Kegiatan Program Pengabdian Kepada Masyarakat (KKNPPM) dalam rangka penerapan teknologi tepat guna dengan maksud untuk meningkatkan kemampuan pasca panen masyarakat Desa Orong Bawa pada tanaman jagung yaitu tanaman jagung menjadi produk diversifikasi bernutrisi dan bernilai jual tinggi, sehingga dapat membantu Pemerintah Daerah Kecamatan Utan dalam peningkatan pendapatan per kapita.

Melalui kegiatan KKN-PPM ini, jagung dapat dikembangkan menjadi produk olahan diversifikasi yang bernutrisi dan bernilai jual tinggi dibandingkan dengan bentuk segarnya, misalnya diolah menjadi Teh Celup Bulu Jagung, Bonggol Jagung untuk Jeli dan Bonggol Jagung untuk Pakan Ternak. Selain itu, dengan adanya diversifikasi olahan jagung menjadi berbagai produk diharapkan akan menambah deretan perbendaharaan hasil olahan jagung dan dapat meningkatkan konsumsi jagung untuk pangan. Hal ini tentunya akan memberikan multiplier effect bagi petani jagung, yaitu memberikan jaminan terserapnya produksi jagung oleh industri pangan dan meningkatnya pendapatan masyarakat petani jagung di Desa Orong Bawa.

\section{METODOLOGI}

\section{Tempat dan Waktu}

KKN-PPM ini dilaksanakan di Desa Orong Bawa Kecamatan Utan. Pelaksanaan kegiatan dilakukan mulai Bulan Juli hingga Agustus 2017 yang meliputi kegiatan survey lokasi, pembekalan, pelaksanaan, hingga tahapan pelaporan.

\section{Kelompok Sasaran}

Program KKN-PPM ini dilaksanakan di Desa Orong Bawa, dengan menyasar 5 kelompok petani yang beranggotakan masing-masing 10 orang. Kelompok-kelompok ini dibentuk dengan dengan memilih petani petani berdasarkan kriteria luas lahan terluas dan jarak sawah terdekat dari desa. Anggota kelompok dipilih secara proporsional dari 3 dusun di Desa Orong Bawa, yaitu Dusun Orong Bawa 1, Dusun Orong Bawa 2 dan Dusun Orong Bawa 3.
Tahapan dan Metode Pelaksanaan Kegiatan

KKN PPM ini terdiri atas beberapa tahapan yaitu: 1) survey lokasi, 2) perseiapan dan pembekalan mahasiswa, 3) sosialisasi program, 3) pelaksanaan kegiatan 4) monitoring dan evaluasi kegiatan.

\section{Target Kegiatan}

Target dari kegiatan ini adalah adanya pengetahuan petani dan Peningkatan produksi diversifikasi olahan jagung ditingkat petani jagung khususnya di Desa Orong Bawa. Kemudian hasil KKN PPM ini dipublikasikan ke dalam Jurnal Tambora, media cetak Gaung dan Radar Sumbawa dan penyusunan buku bahan ajar.

\section{Luaran Kegaitan}

Dalam program KKN-PPM ini beberapa capaian yang menjadi target yang diharapkan antara lain:

1. Adanya peninglatan daya saing diversifikasi produk olahan jagung di Desa Orong Bawa;

2. Peningkatan penerapan iptek dalam menghasilkan diversifikasi produk olahan jaung;

3. Perbaikan sistem dalam hal ini manajemen usaha petani desa Orong Bawa;

4. Peningkatan pendapatan yang bermuara pada peningkatan kesejahteraan petani di Desa Orong Bawa.

\section{HASIL DAN PEMBAHASAN}

\section{Survey Lokasi dan Respon Pemerintah Desa}

Survey lokasi merupakan tahap awal sebagai persiapan KKN PPM. Dilaksanakan pada minggu pertama dan minggu kedua bulan Juli 2018. Pada tahapan ini Ketua Tim dan anggota didampingi panitia KKN dari LPPM UTS turun langsung ke Desa Orong Bawa Kecamatan Utan untuk memastikan kesiapan Desa Orong Bawa menerima mahasiswa yang akan KKN.

Hasil yang dicapai adalah Pemerintah Desa Orong Bawa siap menerima mahasiswa KKN PPM sebanyak 35 orang. Pemerintah Desa Orong Bawa sangat antusias terhadap KKN PPM dan berterimakasih kepada pihak UTS yang telah memilih Desa Orong Bawa sebagai lokasi KKN PPM.

\section{Pendataan, Verifikasi, dan Penetapan Peserta KKN PPM}

Kegiatan ini dilaksanakan pada minggu ketiga bulan Juli 2018. Pada kegiatan ini, panitia KKN UTS melakukan seleksi terhadap mahasiswa calon peserta KKN PPM. Ada beberapa indikator dalam penentuan mahasiswa yang lolos seleksi antara lain : 1) Syarat akademik IPK dan jumlah SKS yang sudah ditempuh; 2) Syarat administrasi yang telah diputuskan pihak universitas; 3) Distribusi setiap program studi harus merata pada setiap kelompok; 


\section{JURNAL TAMBORA}

Vol. 3 No. 1 Februari

2019

dan 4) Basic/disiplin ilmu yang dibutuhkan dalam KKN PPM.

Untuk kegiatan KKN PPM tahun 2018 yang berlokasi di Desa Orong Bawa telah tersaring sebanyak 35 orang yang terdistribusi ke dalam dua kelompok yaitu.

\section{Pembekalan KKN PPM}

Kegiatan ini merupakan kegiatan lanjutan setelah seleksi mahasiswa peserta KKN PPM. Mahasiswa KKN PPM yang keseluruhan berjumlah 35 orang diberikan pembekalan materi seputar kegiatan KKN dengan narasumber dari akademisi dan praktisi. Dari akademisi diwakili oleh Tim LPPM UNSA, sedangkan dari praktisi diwakili oleh perwakilan Dinas Pertanian Kabupaten Sumbawa. Pelaksanaan pembekalan dilaksanakan pada tanggal 27 s.d 28 Juli 2018.

Hasil dari kegiatan ini adalah mahasiswa memilki pengetahuan tentang pelaksanaan KKN meliputi: 1) penyusunan program kerja; 2) pemetaan potensi dan permasalahan desa; 3) mekanisme membuat proposal dan laporan; 4) memilki pengetahuan tambahan terkait dengan beberapa program pelatihan/penyuluhan yang akan dilaksanakan di Desa Orong Bawa.

\section{Kegiatan Penyuluhan dan Pelatihan}

Kegiatan penyuluhan dan pelatihan adalah untuk memberikan pengetahuan dan informasi tentang kompoisisi kimia, kandungan nutrisi dan unsur pangan funsional (nilai tambah) pada jagung. Kegiatan dilaksanakan selama 2 hari yaitu pada tanggal 13 dan 15 Agustus 2018. Peserta yang mengikuti kegiatan penyuluhan tersebut adalah petani Desa Orong Bawa sebanyak 50 orang.

Pelaksanaan penyuluhan selanjutnya adalah tentang "Pengembangan Usaha Diversifikasi Produk Olahan Jagung". Kegiatan ini dilaksanakan selama dua hari, yaitu tanggal 20 s.d 21 Agustus 2018 yang diikuti oleh 50 orang.

Kegiatan selanjutnya yang dilakukan adalah kegiatan praktek langusng membuat aneka produk olahan dari jagung yang dibagikan dalam 3 (tiga) kegiatan yaitu pertama Kegiatan pelatihan yang mengangkat tema: "Diversifikasi Produk Olahan Jagung Pada Teh Celup Bulu Jagung". Kegiatan ini dilaksanakan atau berlangsung selama satu hari, yaitu tanggal 3 September 2018. Kedua Kegiatan pelatihan yang mengangkat tema: "Diversifikasi Produk Olahan Jagung Pada Jeli Dari Bonggol Jagung" Kegiatan ini dilaksanakan atau berlangsung selama satu hari, yaitu tanggal 10 September 2018. Kedua kegiatan tersebut dihadiri oleh 45 orang peserta yang terdiri dari ibu-ibu PKK dan ibu rumah tangga yang merupakan istri petani Desa Orong Bawa

Ketiga Kegiatan pelatihan yang mengangkat tema : "Diversifikasi Produk Olahan Jagung Pada
JURNAL TAMBORA

ISSN 2527-970X | e-ISSN 2621-542X

Pakan Ternak Dari Bonggol Jagung" merupakan program terakhir dari program penyuluhan utama yang direncanakan dalam Program KKN-PPM ini. Kegiatan ini berlangsung selama satu hari, yaitu tanggal 24 September 2018 yang dihadiri oleh 50 orang peserta yang berpropesi sebagai petani.

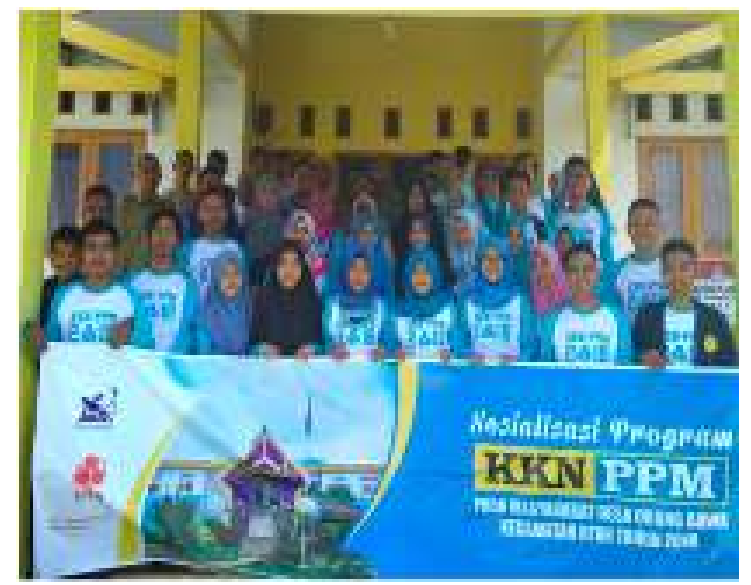

Gambar 1. Sosialisasi Program KKN PPM

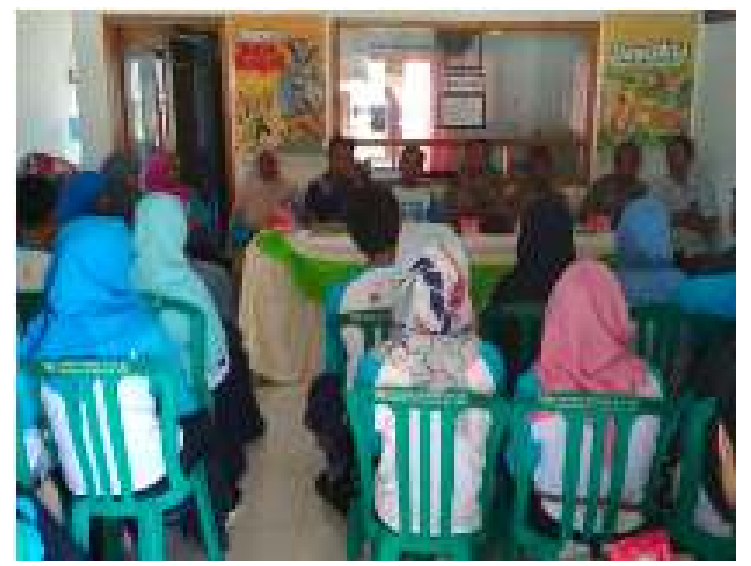

Gambar 2. Penyuluhan komposisi kimia, kandungan nutrisi dan unsur pangan fungsional (nilai tambah) pada jagung

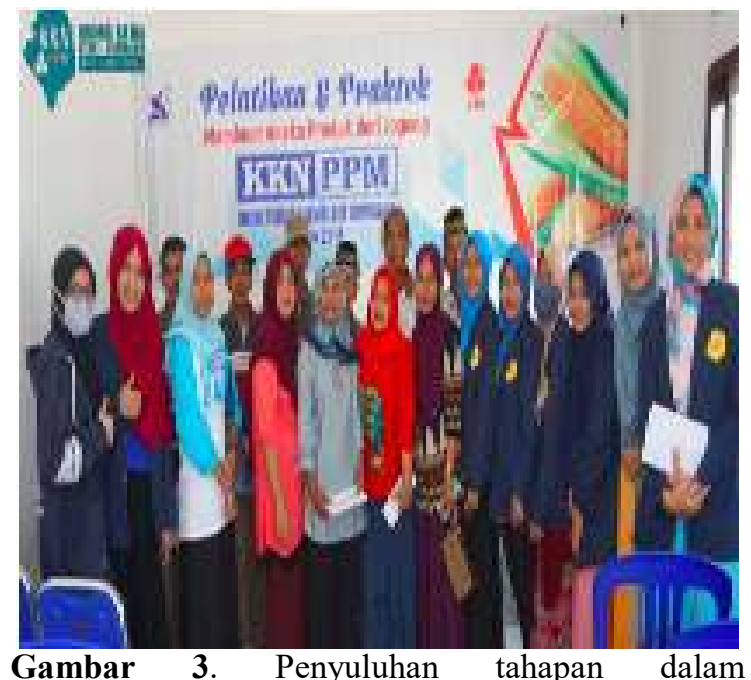
pengembangan usaha diversifikasi produk olahan jagung 


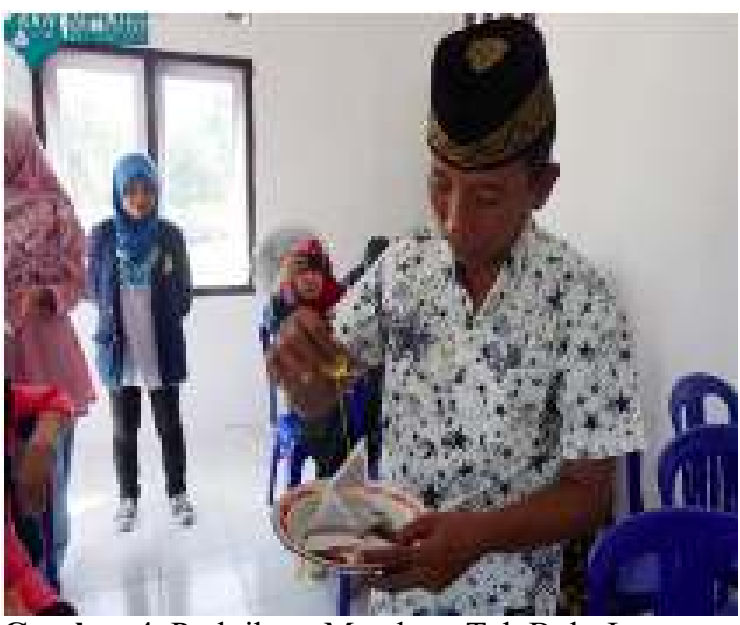

Gambar 4. Praktikum Membuat Teh Bulu Jagung

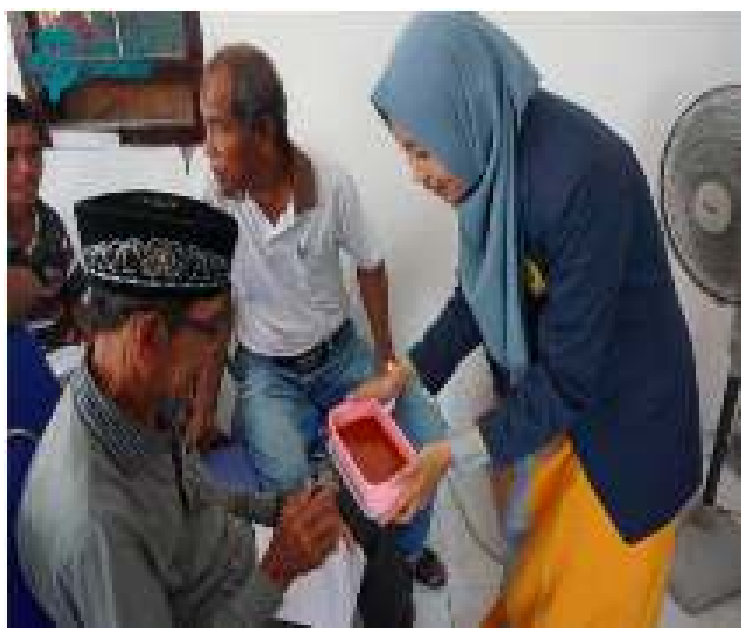

Gambar 5. Praktikum Membuat Jeli Bongkol Jagung

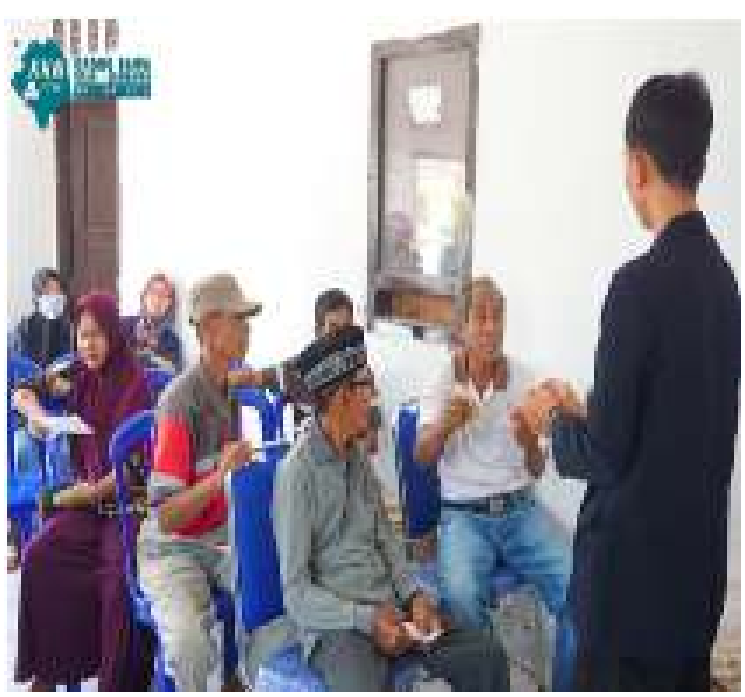

Gambar 6. Praktikum Mebuat Pakan Ternak dari Bongkol Jagung

\section{Kegiatan Monitoring dan Evaluasi}

Tahap evaluasi pelaksanaan program bertujuan untuk mengukur tingkat keberhasilan KKN PPM yang diterapkan. Tahap evaluasi meliputi evaluasi tiap tahap pelaksanaan kegiatan dan evaluasi secara keseluruhan. Evaluasi tiap tahap kegiatan dilakukan setelah selesainya tahapan kegiatan guna melihat tingkat keberhasilan dan menjadi bahan pertimbangan untuk kegiatan berikutnya. Evaluasi keseluruhan dilakukan setelah program atau kegiatan KKN PPM selesai dilaksanakan. Evaluasi akan dilakukan pada beberapa hal sebagai berikut:

1) Tingkat partisipasi mitra pada setiap kegiatan.

Evaluasi terhadap tingkat partisipasi dilakukan pada setiap rangkaian kegiatan dengan cara memonitoring dan mengevaluasi jumlah kehadiran anggota kelompok mitra (peserta pelatihan). Dari hasil evaluasi didapatkan bahwa partisipasi masyarakat Desa Orong Bawa sangat tinggi untuk kegiatan ini terbukti dengan tingkat kehadiran peserta sesuai dengan yang diharapkan, disamping itu antusias masyarakat mengikuti kegiatan juga sangat besar dimana peserta mengikuti seluruh rangkaian kegiatan hingga kegiatan berakhir.

2) Tingkat pengetahuan mitra dalam memahami materi penyuluhan.

Evaluasi ini dilakukan pada tahap awal dan akhir kegiatan pelatihan untuk meninjau tingkat pengetahuan kelompok mitra sebelum dan setelah diadakannya kegiatan KKN PPM dengan metode kuesiner dan wawancara..

3) Tingkat keterampilan mitra dalam membuat aneka produk olahan dari jagung, menerapkan teknologi pertanian.

Evaluasi dilakukan terhadap ketrampilan kelompok mitra dengan metode pengamatan secara langsung pada masing-masing individu peserta pelatihan/penyuluhan.

\section{PENUTUP}

\section{Kesimpulan}

Kesimpulan dari KKN PPM ini adalah:

1) $80 \%$ anggota masyarakat aktf dalam melaksanakan kegiatan Pelatihan/penyuluhan dan pendampingan. Anggota masyarakat sebagian besar telah memahami tema yang menjadi materi penyuluhan/pelatihan.

2) Program KKN PPM telah dipublikasikan pada media cetak Gaung dan Radar Sumbawa, sehingga program ini sudah diketahui oleh masyarakat luas. î́

\section{Saran}

Kegiatan ini mendapat respon positiv dari masyarakat. Selanjutnya, perlu ada langkah-langkah strategis dari pemerintah Desa Orong Bawa untuk 
melanjutkan kegiatan yang menjadi program KKN PPM ini secara lebih luas dan kontinyu agar pendapatan petani Desa Orong Bawa pada khususnya dan masyarakat pada umumnya terus meningkat, sehingga mampu mengangkat taraf hidup masyarakat Desa Orong Bawa pada tingkat sejahtera.

\section{REFERENSI}

Anonim. 2012. Kecamatan Dalam Angka Tahun 2012. Sumbawa : Badan Pusat Statistik.

Aprini, Nisma. 2015. Kajian Penerapan Kelembagaan Corporate Farming Pada Usahatani Padi Ekosistem Pasang Surut Di Kabupaten Ogan Komering Ilir Provinsi Sumatera Selatan. Prosiding Seminar Nasional Lahan Suboptimal 2015, Palembang 08-09 Oktober 2015. ISBN : $979-$ $587-580-9$

Arsyad, Lincolin. 2005. An Assesment of Microfinance Institution Performance : The Importance of Institutional Environment. Gadjah Mada International Journal of Business 7(3) : $391-472$.

Badan Pusat Statistik (BPS), 2013. Kecamatan Utan Dalam Angka 2016. BPS Kabupaten Sumbawa

Kasmir. 2003. Manajemen Perbankan. PT. Raja Grafindo Persada, Jakarta.

Kuncoro Mudrajad. 2004. Otonomi Dan pembangunan Daerah: Reformasi, Perencanaan, Strategi dan Peluang. Erlangga. Jakarta.

M. Lumintang Fatmawati. 2013. Analisis Pendapatan Petanu Padi di desa Tetep Kecamatan Langowan Timur. Jurnal EMBA Vol 1 No.3 September 2013

Soekartawi Dkk, 2001. Ilmu Usaha Tani. Jakarta : UI Press

Suryawati, C. 2005. Memahami Kemiskinan Secara Multidimensi. Jurnal Agroekonomi Vol. 08(03) September 2005 